

\section{NOTICE}

The submitted manuscript has been offered by an employee of the Alliance for Sustainable Energy, LLC (ASE), a contractor of the US Government under Contract No. DE-AC36-08-GO28308. Accordingly, the US Government and ASE retain a nonexclusive royalty-free license to publish or reproduce the published form of this contribution, or allow others to do so, for US Government purposes.

This report was prepared as an account of work sponsored by an agency of the United States government. Neither the United States government nor any agency thereof, nor any of their employees, makes any warranty, express or implied, or assumes any legal liability or responsibility for the accuracy, completeness, or usefulness of any information, apparatus, product, or process disclosed, or represents that its use would not infringe privately owned rights. Reference herein to any specific commercial product, process, or service by trade name, trademark, manufacturer, or otherwise does not necessarily constitute or imply its endorsement, recommendation, or favoring by the United States government or any agency thereof. The views and opinions of authors expressed herein do not necessarily state or reflect those of the United States government or any agency thereof.

Available electronically at http://www.osti.gov/bridge

Available for a processing fee to U.S. Department of Energy and its contractors, in paper, from:

U.S. Department of Energy

Office of Scientific and Technical Information

P.O. Box 62

Oak Ridge, TN 37831-0062

phone: 865.576 .8401

fax: 865.576 .5728

email: mailto:reports@adonis.osti.gov

Available for sale to the public, in paper, from:

U.S. Department of Commerce

National Technical Information Service

5285 Port Royal Road

Springfield, VA 22161

phone: 800.553.6847

fax: 703.605.6900

email: orders@ntis.fedworld.gov

online ordering: http://www.ntis.gov/ordering.htm 


\title{
A STUDY ON THE HUMIDITY SUSCEPTIBILITY OF THIN-FILM CIGS ABSORBER
}

\author{
F. J. Pern, B. Egaas, B. To, C.-S. Jiang, Jian V. Li, S. Glynn, and C. DeHart \\ National Center for Photovoltaics, National Renewable Energy Laboratory, 1617 Cole Blvd., Golden, CO 80401
}

\begin{abstract}
The susceptibility of a thermally co-evaporated CulnGaSe ${ }_{2}$ (CIGS) thin-film absorber to humidity and its consequence on composition, morphology, electrical and electronic properties, and device efficiency was investigated. CIGS films on Mo-coated soda lime glass were degraded either in the ambient at $\sim 21^{\circ} \mathrm{C}$ and $\sim 21 \%$ relative humidity $(\mathrm{RH})$ for a period of several months or in damp heat $(\mathrm{DH})$ at $85^{\circ} \mathrm{C}$ and $85 \% \mathrm{RH}$ briefly for $15-30 \mathrm{~min}$; then the films were processed simultaneously into devices in a batch that included an unexposed control. In addition to severe delamination on some samples of the absorber films, prolonged ambient exposure resulted in numerous "spot" formations that lost CIGS with scale-like disintegration rippling around the spots and showed a significant presence of $\mathrm{Na}$. Exposure in $\mathrm{DH}$ for $5 \mathrm{~h}$ was able to reproduce the spot formations on the CIGS films. A significant to large decrease of cell efficiency was observed from $14 \%-16 \%$ for the unexposed control to $8 \%-11 \%$ for the CIGS absorber exposed in DH for 15 and 30 min and $1 \%-4 \% \%$ for the ambient-degraded CIGS with high series resistance and very low shunt resistance.
\end{abstract}

\section{INTRODUCTION}

Long-term performance reliability of thin-film photovoltaics such as CIGS and CdTe is highly important to their success in gaining broad market acceptance. Packaging capable of blocking or minimizing moisture ingress is essential for PV modules to protect an absorber such as CIGS, window layer such as $\mathrm{ZnO}$, and contact electrode such as Mo from humidity-induced damages and therefore to ensure their durability in the field. For example, Siemens Solar (which is no longer operating) employed a moisture-blocking desiccant-type edge sealant and a TPAT (Tedlar/polyester/aluminum foil/Tedlar) on its CIGS modules. Edge sealants are also beneficially used on glass/glass laminates of CIGS and CdTe modules. The Olson group has developed a multilayer moisture-barrier coating to successfully protect CIGS from $\mathrm{DH}$ at

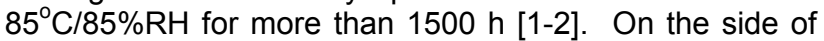
materials stability, several groups have conducted accelerated stress tests on either complete cells or minimodules in damp heat, light/dark cycles, or both $\mathrm{DH} /$ light exposures [3-11], to better assess the performance stability and understand the degradation mechanisms of CIGS absorbers or devices. Longer-term outdoor performance reliability of CIS and CIGS modules was reported by del Cueto at al. recently [12]. Various factors or mechanisms ranging from increased defect density [3-5] to increased resistance of $\mathrm{ZnO}$ window layer $[10,11]$ have been proposed to explain the differences observed in CIGS device or module degradation behaviors. However, a common issue in such approaches is that using complete devices or (mini-) modules make it difficult to properly differentiate, and/or separate, the factors that contribute to degradation from among the different component materials. In recognizing the instability issues imparted by the main CIGS components, Wennerberg et al. attempted to improve the performance and stability by design modifications [13]. Previously we have demonstrated the instability of Mo back electrode and intrinsic and Al-doped $\mathrm{ZnO}$ upon $\mathrm{DH}$ exposures [14-16]. To eliminate the ambiguity of uncertain contributions from various degrading factors encountered in testing complete CIGS cells or mini-modules, we chose in this work to only investigate only the humidity susceptibility of the absorber by subjecting the CIGS samples to ambient environment over a prolonged period of several months and to $\mathrm{DH}$ condition over a very brief period of hours or less. The ambient and $\mathrm{DH}$-exposed CIGS absorber samples, along with an unexposed control, were then processed simultaneously in a batch into devices. This approach effectively removed the potential variations and uncertainty that would have been found had the devices were fabricated separately. Meanwhile, other studies at NREL also examined the lifetime and stability of the CIGS absorber and partial device structures exposed to the air or stored in a $\mathrm{N}_{2}$ dry box by using photoluminescence analysis [17-18].

\section{EXPERIMENTAL}

Samples and cell fabrication: CIGS absorbers were deposited by NREL's three-stage thermal co-evaporation process on Mo-coated soda lime glass. The standard device fabrication process involved CdS by chemical bath deposition, intrinsic-/Al-doped bilayer $\mathrm{ZnO}$ window by sputter deposition, and $\mathrm{Ni} / \mathrm{Al}$ contact electrode by e-beam evaporation.

Exposures: Some absorber samples placed in clear plastic boxes were allowed to expose to the ambient for 812 months inside the laboratory building, which was typically at $\sim 21^{\circ} \mathrm{C}$ and $\sim 21 \% \mathrm{RH}$. Another set of absorber samples was cut from a large piece into four portions, one of which was stored in a $\mathrm{N}_{2}$ dry box as the control until the moment of device fabrication. The other pieces were exposed in a Blue $\mathrm{M}$ chamber operated at $85^{\circ} \mathrm{C}$ and $85 \%$ $\mathrm{RH}$ briefly for either 15 or 30 min. Smaller specimens for morphological and microscopic studies were $\mathrm{DH}$-exposed accumulatively from 0.5 to 1,2 , and 5 hours. 
Characterization: Surface morphological features and changes were examined by an optical microscope at low magnification factors, a WYKO interference optical microscope at high resolutions, and an FEI Nova NanoSEM 630 scanning electron microscope (SEM). Localized small-area composition analysis was performed by using a JEOL 8900 Superprobe electron probe microanalysis (EPMA) with a typical $\sim 20-\mu$ m probe size. Distribution of work function was examined using scanning Kelvin probe force microscopy (SKPFM) $[19,20]$ with fine resolutions of several tens of nanometers. SKPFM is based on the non-contact mode of atomic force microscopy (AFM), and measures surface potential/work function by measuring a coulomb force between the AFM tip and sample. Admittance spectroscopy measurements were conducted by using an Agilent A4294 impedance analyzer, typically with an $\mathrm{AC}$ modulation voltage of 45 $\mathrm{mV}_{\mathrm{rms}}$ at a frequency of $10 \mathrm{kHz}$.

\section{RESULTS AND DISCUSSION}

Compositional Changes. The CIGS absorber films upon prolonged ambient or 5-h $\mathrm{DH}$ exposures exhibited numerous visible spots. Some ambient-degraded films even became wrinkled and delaminated. Some results of localized composition analysis by EPMA at $10 \mathrm{KeV}$ are given in Table 1 for two samples ( $A$ and $B$ ) before and after prolonged degradation by ambient exposure. Sample A was a Ga-rich film, and sample B had a typical CIGS film composition. When elemental weight percentages are compared, the compositions of the ambient-degraded but still smooth regions on sample $A$ are similar to those of the initial film; however, the spotty areas are relatively low in $\mathrm{Cu}, \mathrm{Ga}$ and Se. Greater compositional changes are seen for the spotty areas on sample B than that for sample $A$. Upon normalization to the atomic ratio percentage, the spotty areas are comparatively low in $\mathrm{Ga}$ for both samples. Significant presence of $\mathrm{Na}$ was also found at the spotty formations, but its concentration was difficult to quantify.

Morphological and Optical Changes. The optical images in Fig. 1 show the visible spots on the CIGS films. As revealed from examination under a WYKO interference microscope, the spot formations are in fact small regions of CIGS that were disintegrated (lost) with finite scale-like lines rippling around the spots (figures not shown). The SEM micro-images in Fig. 2 compare the surface morphology of a still smooth area near the spot formation

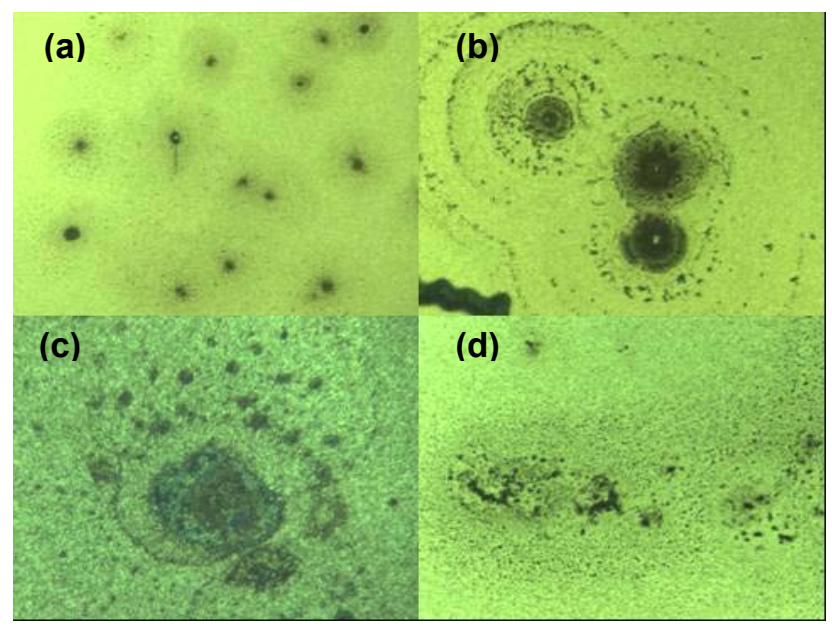

Fig. 1. Optical images with artificial green color of some spot formations on ambient-degraded CIGS films at a magnification of $10 X(a), 16 X(b)$, or $40 X(c, d)$.

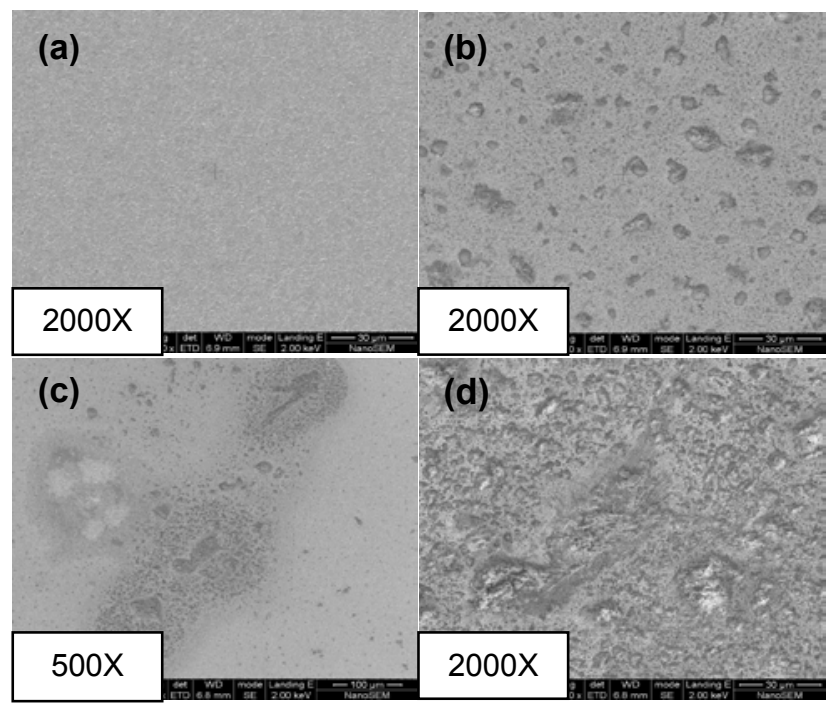

Fig. 2. SEM micrographs for an ambient-degraded sample (\#A, Table 1) over several months: (a) a still "smooth" area, (b) an area with a large number of small pits, and (c, d): large pitting spots, which were visible and corresponded to the images seen under the optical and interference microscopes. The magnification factors are indicated in the micrographs.

Table 1. Compositions for CIGS Absorber Films with or without Exposure to Ambient or Damp Heat

\begin{tabular}{|c|c|c|c|c|c|c|c|c|c|c|c|c|}
\hline \multirow{2}{*}{$\begin{array}{c}\text { Sample } \\
\text { ID }\end{array}$} & \multirow[t]{2}{*}{ Exposure } & \multirow[t]{2}{*}{ Area } & \multicolumn{5}{|c|}{ Weight Percent (Average of 5 points) } & \multicolumn{5}{|c|}{ Atomic Ratio (Average of 5 points) } \\
\hline & & & $\mathrm{Cu}$ & In & Ga & $\mathrm{Se}$ & Total & $\mathrm{Cu}$ & In & Ga & $\mathrm{Se}$ & Total \\
\hline \multirow[t]{3}{*}{ A } & No (Initial) & smooth & 17.23 & 22.76 & 10.27 & 51.25 & 101.50 & 21.42 & 15.66 & 11.64 & 51.28 & $\overline{100.00}$ \\
\hline & Ambient & smooth & 17.20 & 23.44 & 9.82 & 51.15 & 101.60 & 21.42 & 16.16 & 11.15 & 51.28 & 100.00 \\
\hline & Ambient & spotty & 15.59 & 21.07 & 8.74 & 47.61 & 93.01 & 21.10 & 15.82 & 10.79 & 52.29 & 100.00 \\
\hline \multirow[t]{2}{*}{ B } & Ambient & smooth & 18.97 & 26.57 & 7.21 & 50.30 & 103.05 & 23.50 & 18.21 & 8.14 & 50.15 & 100.00 \\
\hline & Ambient & spotty & 12.19 & 17.89 & 4.40 & 34.39 & 68.87 & 22.37 & 18.43 & 7.11 & 52.08 & 100.00 \\
\hline
\end{tabular}


and the spot for an ambient-degraded CIGS sample. A large degree of morphological (and compositional, above) disintegration was present, especially around the spot formations. Optically, despite the presence of visible spotty formations and some degree of delamination, the ambient-degraded CIGS films showed essentially identical reflectance spectra in the 250-900-nm range, but a consistent peak shift of $\sim 30-40 \mathrm{~nm}$ in the interference pattern in the $900-1500-n m$ range, as seen in Fig. 3. Currently, it can not be clearly determined if this spectral shift is caused by certain changes in film thickness, nonuniformity, optical density, or compositions.

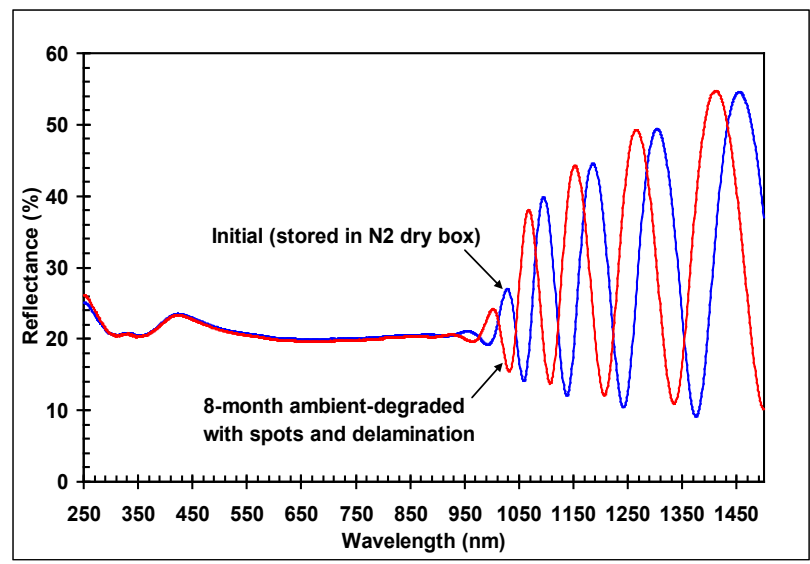

Fig. 3. Reflectance spectra for a CIGS absorber film on Mo/SLG substrate before and after 8-month ambient exposure.

SKPIAFM Analysis. The scanning Kevin probe/AFM (SKPFM) was employed to examine the effect of $\mathrm{DH}$ exposure on the electronic property (work function or surface potential). The SKPFM and AFM images taken before a $\mathrm{DH}$ exposure, shown in column (a) in Fig. 4,

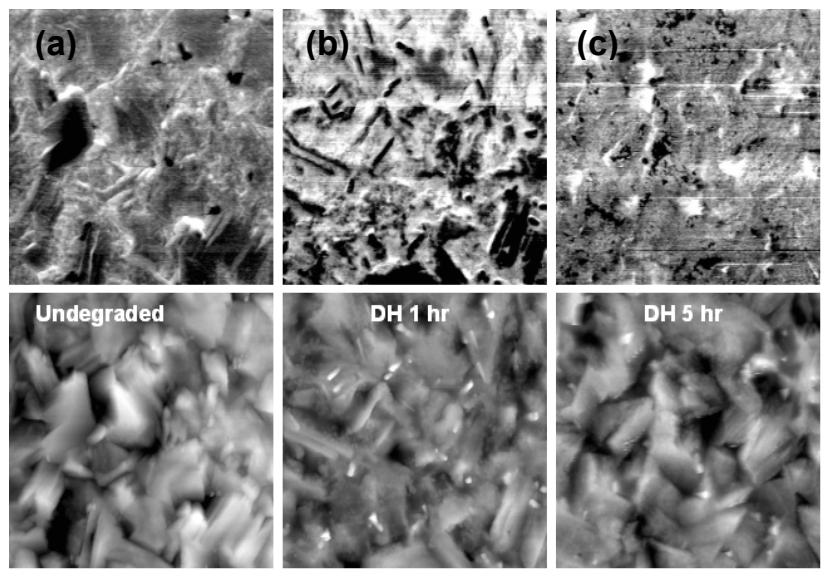

Fig. 4. Corresponding scanning Kelvin probe (SKP, top row) and AFM (bottom row) images for $\mathrm{DH}$ degraded CIGS on Mo/SLG: column (a) undegraded specimen, (b) 1-h DH exposure, and (c) 5-h DH exposure. exhibit typical CIGS topographic features and a welldefined work-function mapping. The grain topography and work function distribution appear to show well-defined correlations; that is, the work function depends closely on the grains' surface facets and its values on the grain boundaries may depend on specific grain boundary structures. Small spots appeared on the AFM images after 1- and 5-h DH exposures (columns [b, c], bottom). The SKPFM images show significant changes with the $\mathrm{DH}$ exposures, suggesting that the work function had gradually lost its correlation with the grain geometric feature upon $\mathrm{DH}$ exposure. After $5 \mathrm{~h}$ in $\mathrm{DH}$, the initially well defined work-function images became fairly blurred, likely a result of electronic property breakdown on the CIGS grains.

The sensitivity of the CIGS absorber to the environment (humidity and oxygen) was evidenced by the rapid decline of carrier lifetime after exposing it to the air for only one day, as observed by Metzger et al. in their studying the stability of CIGS absorber films using photoluminescence $[17,18]$. The degradation was greatly reduced if the CIGS was quickly deposited with CdS; the CIGS/CdS was found stable in the air for months $[17,18]$. The stabilization mechanism of CdS for CIGS is not clear, however. On the other hand, Würz et al. reported the formation of a $\mathrm{Cu}(\mathrm{OH})_{2}$ surface phase on the $\mathrm{CuGaSe}_{2}$ that was stored in the ambient for several months [21]. Heske et al. reported the formation of sulfate, which resulted from sulfur oxidation induced by $\mathrm{DH}$ in the $\mathrm{Cu}(\mathrm{In}, \mathrm{Ga})(\mathrm{S}, \mathrm{Se})_{2}$, CIGSSe-based solar cells [22]. While more in-depth studies are required, it is likely that the CIGS absorber thin films have undergone similar oxidation/hydrolysis when exposed in the ambient as well as in the damp heat.

Admittance Spectroscopy Measurements. To gain understanding of the interface and bulk electrical properties [23,24], we also conducted some capacitance (C) measurements dependent on both frequency (f) and bias voltage $(\mathrm{V})$, i.e., bias dependent admittance spectroscopy on the complete cells. Figure 5(a) shows a 3-D plot of the admittance spectroscopy of a device made of a CIGS sample treated in $\mathrm{DH}$ for $15 \mathrm{~min}$ as a function of both the reverse-bias voltage and measurement temperature. The signatures of two trap levels are evident: one corresponding to the bulk states with its activation energy $(\sim 140 \mathrm{meV})$ essentially independent of bias voltage and the other was clearly influenced by the increasing bias voltage. Figure $5(\mathrm{~b})$ shows the activation energy for the deep level states as a function of bias voltage for the devices on four different cell samples. The activation energy of those states was obtained from the Arrhenius plot of frequency versus temperature at which the differential capacitance $\mathrm{fdC} / \mathrm{d}[\mathrm{In}(\mathrm{f})]$ spectrum peaks. The results show that ambient and $\mathrm{DH}$ degradation introduces a deep level of $>400 \mathrm{meV}$. This level is absent in the unexposed reference control sample. Because the activation energy of this deep level increases with reverse bias, the deep level apparently originates from interface states $[25,26]$. In comparison, Deibel et al. reported an 

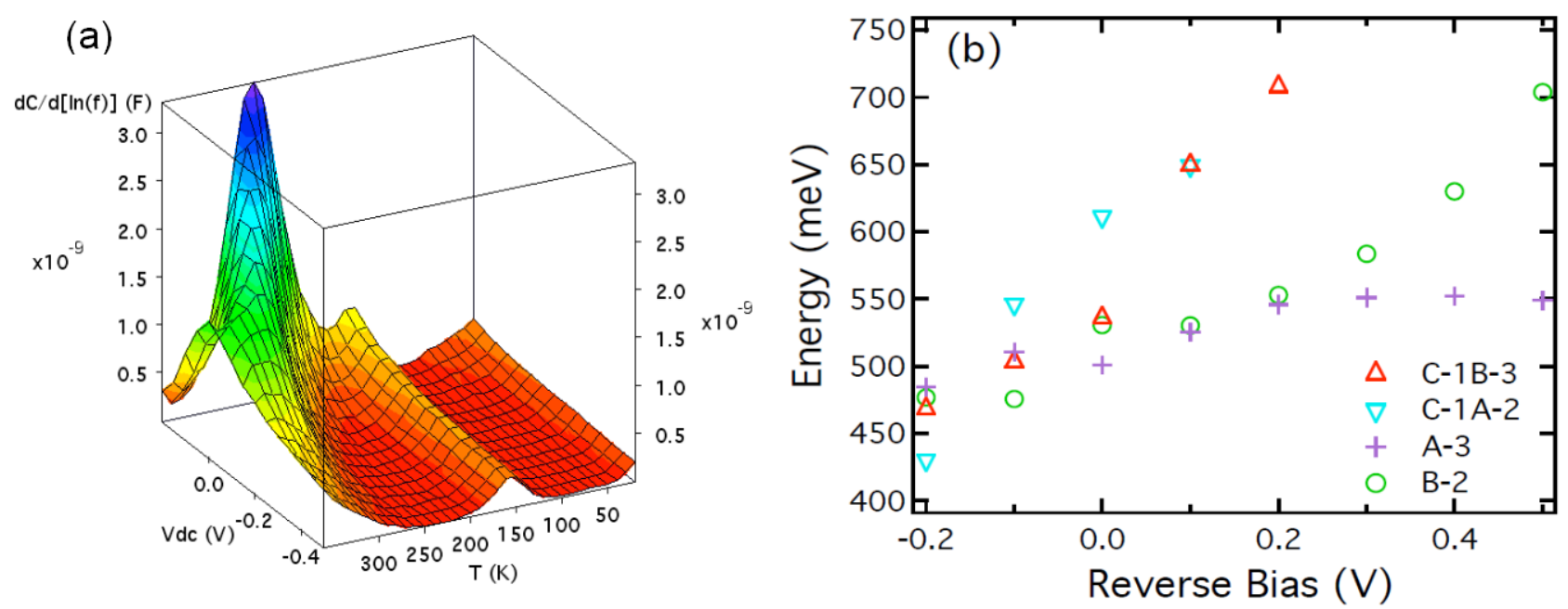

Fig. 5. (a) A 3-D plot of admittance spectroscopy as a function of temperature and bias for a 15-min, DH-treated CIGS device (C-1B-1, Table 2), and (b) the activation energy of deep-level states as a function of bias voltage for the devices on four samples with device numbers indicated in the legends (see Table 2 for the exposure treatments of the CIGS absorber films).

Table 2. Cell Parameters for CIGS Samples with or without Exposure to Ambient or Damp Heat

\begin{tabular}{|ccccccccc|}
\hline $\begin{array}{c}\text { Sample } \\
\text { ID }\end{array}$ & Exposure & $\begin{array}{c}\text { Device } \\
\text { No. }\end{array}$ & $\begin{array}{c}\text { Voc } \\
(\mathbf{V})\end{array}$ & $\begin{array}{c}\text { Jsc } \\
\left(\mathbf{m A} / \mathbf{c m}^{2}\right)\end{array}$ & $\begin{array}{c}\text { FF } \\
(\%)\end{array}$ & $\begin{array}{c}\text { Eff } \\
(\%)\end{array}$ & $\begin{array}{c}\text { Rs } \\
\text { (ohm-cm) }\end{array}$ & $\begin{array}{c}\text { Rsh } \\
\text { (ohm-cm) }\end{array}$ \\
\hline A & ambient & 1 & 0.415 & 10.30 & 34.3 & 1.5 & 16.8 & 58 \\
& & 3 & 0.436 & 6.44 & 31.6 & 0.9 & 33.3 & 78 \\
B & ambient & 1 & 0.411 & 22.89 & 40.5 & 3.8 & 6.9 & 44 \\
& & 4 & 0.385 & 25.67 & 44.9 & 4.4 & 4.5 & 55 \\
C-1A & DH 15 min & 2 & 0.544 & 30.84 & 65.6 & 11.0 & 2.5 & 413 \\
& & 4 & 0.560 & 32.04 & 66.0 & 11.8 & 2.4 & 628 \\
C-1B & DH 30 min & 1 & 0.512 & 30.20 & 64.4 & 10.0 & 2.8 & 504 \\
& & 3 & 0.513 & 30.91 & 63.7 & 10.1 & 2.8 & 376 \\
C-0A & No & 1 & 0.654 & 30.28 & 71.1 & 14.1 & 1.7 & 4491 \\
& (N2 dry box $)$ & 7 & 0.652 & 31.39 & 76.9 & 15.7 & 1.4 & 14126 \\
C-0B & No & 1 & 0.668 & 29.78 & 71.2 & 14.1 & 2.1 & 4228 \\
& (N2 dry box) & 5 & 0.672 & 31.10 & 77.2 & 16.1 & 1.4 & 20536 \\
\hline
\end{tabular}

activation energy of 160-180 meV for the interface states in a device made of CIGSSe absorber that was $\mathrm{DH}$ treated for $24 \mathrm{~h}$ prior to device fabrication; and the activation energy of the interface states ranged from 85 to $340 \mathrm{meV}$ for their devices exposed to $\mathrm{DH}$ ranging from 2 to $438 \mathrm{~h}$, as determined from C-V measurements at $90^{\circ} \mathrm{K}$ with a frequency of $100 \mathrm{kHz}[4,5]$.

Cell Efficiency Changes. The unexposed and ambient- and DH-exposed CIGS absorber samples were fabricated into cells simultaneously in a batch having a common configuration of SLG/Mo/CIGS/CdS/bi-layer ZnO. The cell efficiencies were also measured all in one session. Some of the cell I-V parameters are given in Table 2. It is obvious that the prolonged ambient exposure (samples $A$ and $B$ ) resulted in very poor devices due to substantial compositional and morphological degradations on the absorber films. The devices' high series resistance (Rs) and low shunting resistance (Rsh) suggest that shorting and shunting had occurred. Even brief exposures in $\mathrm{DH}$ for $15 \mathrm{~min}$ and $30 \mathrm{~min}$ induced significant efficiency losses as evidenced by samples $\# \mathrm{C}-1 \mathrm{~A}$ and $1 \mathrm{~B}$, respectively, when compared to the unexposed control samples (samples $\mathrm{C}-0 \mathrm{~A}$ and $\mathrm{C}-\mathrm{OB}$ ). The $\mathrm{C}-0$ and $\mathrm{C}-1$ samples were made from specimens cut from the same piece of CIGS film on Mo/SLG.

\section{CONCLUSIONS}

We have shown the detrimental consequences in CIGS absorbers that were subjected to low humidity levels over prolonged periods at ambient temperature and high humidity at a high temperature in a $\mathrm{DH}$ environment. The humidity susceptibility of the CIGS absorber resulted in 
compositional, morphological, and electrical deteriorations, which in turn caused the loss of cell performance. More work is on-going to further evaluate the sensitivity of CIGS absorber to various $\mathrm{RH}$ levels and temperatures.

\section{ACKNOWLEDGEMENTS}

We thank Drs. R. Noufi and I. L. Repins for discussions and kind offering of some CIGS absorber samples. We also thank Drs. M. Contreras and T. Gessert for their support of this study. This work was performed at the National Center for Photovoltaics under DOE contract number DE-AC36-08G028308 with the National Renewable Energy Laboratory.

\section{REFERENCES}

[1] L. C. Olson, S. N. Kundu, M. E. Gross, and A. Joly, "Damp Heat Effects on CIGSS and CdTe Cells," Proc. of 2007 DOE Solar Technology Program Review Meeting, April 17-19, Denver, CO.

[2] L. C. Olson, M. E. Gross, and S. N. Kundu, "Properties of Encapsulated CIGS Cells in $85^{\circ} \mathrm{C} / 85 \% \mathrm{RH}$," Proc. of 33rd IEEE PVSC, May 11-16, 2008, San Diego, CA.

[3] M. Schmidt, D. Braunger, R. Schaffler, H. W. Schock, and U. Rau, "Influence of damp heat on the electrical properties of $\mathrm{Cu}(\mathrm{In}, \mathrm{Ga}) \mathrm{Se}_{2}$ solar cells," Thin Solid Films, 361-362, 2000, pp. 283-287.

[4] C. Deibel, V. Dyakonov, J. Parisi, J. Palm, S. Zweigart, F. Karg, "Influence of damp heat testing on the electrical characteristics of $\mathrm{Cu}(\mathrm{In}, \mathrm{Ga})(\mathrm{S}, \mathrm{Se})_{2}$ solar cells," Thin Solid Films, 403-404, 2002, pp. 325-330.

[5] C. Deibel, V. Dyakonov, and J. Parisi, "Defect Spectroscopy on Damp-Heat Treated ZnO/CdS/ $\mathrm{Cu}(\mathrm{In}, \mathrm{Ga})(\mathrm{S}, \mathrm{Se})_{2} / \mathrm{Mo}$ Heterojunction Solar Cells," Verlag der Zeitschrift für Naturforschung 09320784/03/1200, 2003, pp. 691-702, Tübingen.

[6] T. Yanagisawa and T. Kojima, "The Stability of the CulnSe $\mathrm{S}_{2}$ Solar Mini-Module I-V Characteristics under Continuous and Light/Dark Irradiation Cycle Tests," Microelectronics Reliability, 43, 2003, pp. 503-507.

[7] T. Yanagisawa, T. Kojima, and T. Koyanagi, "Behavior of $\mathrm{Cu}(\mathrm{In}, \mathrm{Ga}) \mathrm{Se}_{2}$ Solar cells under Light/Damp Heat over Time," Microelectronics Reliability, 44, 2004, pp. 229-235.

[8] G. A. Medvedkin, E. I. Terukov, K. Sato, Yu. Hasegava, and K. Hirose, "Photoluminescence Properties of Polycrystalline $\mathrm{ZnO} / \mathrm{CdS} / \mathrm{CulnGaSe}_{2}$ Solar Cells at a Low Temperature," Semiconductors, 35, 2001, pp. 1329-1334.
[9] G. A. Medvedkin, E. I. Terukov, Y. Hasegawa, K. Hirose, K. Sato, "Microdefects and Point Defects Optically Detected in $\mathrm{Cu}(\mathrm{In}, \mathrm{Ga}) \mathrm{Se}_{2}$ Thin Film Solar Cells Exposed to The Damp and Heating," Sol. Energy Mater. \& Sol. Cells, 75, 2003, pp. 127-133.

[10] J. Klaer, R. Klenk, A. Boden, A. Neisser, C. Kaufmann, R. Scheer, and H.-W. Schock, "Damp Heat Stability of Chalcopyrite Mini-Modules: Evaluation of Specific Test Structures," Proc. 31st IEEE PVSC, 2005, pp. 336-339.

[11] R. Feist, S. Rozeveld, M. Mushrush, R. Haley, B. Lemon, J. Gerbi, B. Nichols, R. Nilsson, T. Richardson, S. Sprague, R. Tesch, S. Torka, C. Wood, S. Wu, S. Yeung, M. T. Bernius, "Examination of Lifetime-Limiting Failure Mechanisms In CIGSSBased PV Minimodules Under Environmental Stress," Proc. of 33rd IEEE PVSC, May 11-16, 2008, San Diego, CA.

[12] J. A. del Cueto, S. Rummel, B. Kroposki, A. Anderberg, "Long-Term Performance Data and Analysis of CIS/CIGS Modules Deployed Outdoors," Proc. SPIE PV Conference on Photovoltaic Cell and Module Technologies II (\#7045), Aug. 10-11, 2008, San Diego, CA.

[13] J. Wennerberg, J. Kessler, and L. Stolt, "Cu(In, Ga)Se Sed $_{2}$ - Thin-Film Photovoltaic Modules Optimized for Long-Term Performance," Sol. Energy Mater. \& Sol. Cells, 75, 2003, pp. 47-55.

[14] J. Pern and R. Noufi, "An Investigation of Stability Issues of $\mathrm{ZnO}$ and Mo on Glass Substrates for CIGS Solar Cells upon Accelerated Weathering and Damp Heat Exposures," Poster and Proc. of DOE Solar Energy Technology Program Review Meeting, April 17-19, 2007, Denver, CO.

[15] F.J. Pern, R. Noufi, X. Li, C. DeHart, and B. To, "Damp-Heat Induced Degradation of Transparent Conducting Oxides for Thin-Film Solar Cells," Proc. of 33rd IEEE PVSC, May 11-16, 2008, San Diego, CA.

[16] F. J. Pern, R. Noufi, B. To, C. DeHart, X. Li, and S. H. Glick, "Degradation of ZnO-based Window Layers for Thin-Film CIGS by Accelerated Stress Exposures," Proc. of SPIE PV Reliability Conference, August 1014, 2008, San Diego, CA.

[17] W. K. Metzger, I. L. Repins, M. Romero, P. Dippo, M. Contreras, R. Noufi, and D. Levi, "Recombination Kinetics and Stability in Polycrystalline $\mathrm{Cu}(\mathrm{In}, \mathrm{Ga}) \mathrm{Se}_{2}$ Solar Cells," Thin Solid Films, 517, 2009, pp. 23602364.

[18] W. K. Metzger, I. L. Repins, and M. A. Contreras, "Long Lifetimes in High-Efficiency $\mathrm{Cu}(\mathrm{In}, \mathrm{Ga}) \mathrm{Se}_{2}$ Solar 
Cells," App. Phys. Lett., 93, 2008, pp. 022110-1022110-3.

[19] M. Nonnenmacher, M. P. O'Boyle, and H. K. Wickramasinghe, "Kelvin Probe Force Microscopy," Appl. Phys. Lett., 58, 1991, pp. 2921-2923.

[20] C.-S. Jiang, H. R. Moutinho, D. J. Friedman, J. F. Geisz, and M. M. Al-Jassim, "Measurement of Built-in Electrical Potential in III-V Solar Cells by Scanning Kelvin Probe Microscopy," J. Appl. Phys., 93, 2003, pp. 10035-10040.

[21] R. Würz, A. Meeder, D. Fuertes Marrón, Th. SchedelNiedrig, and K. Lips, "An Electron Paramagnetic Resonance and Photoelectron Spectroscopy Study on the Native Oxidation of $\mathrm{CuGaSe}_{2}$," MRS Symp. Proc. 865, 2005, pp. F5.36.1-F5.36.6.

[22] C. Heske, U. Groch, L. Weinhardt, O. Fuchs, B. Holder, E. Umbach, C. Bostedt, L. J. Terminello, S. Zweigart, T. P. Niesen, and F. Karg, "Damp Heat-Induced Sulfate Formation in $\mathrm{Cu}(\mathrm{In}, \mathrm{Ga})(\mathrm{S}, \mathrm{Se})_{2}$-based Thin Film Solar Cells," Appl. Phys. Lett., 81, 2002, pp. 4550-4552.

[23] T. Kojima, T. Koyanagi, K. Nakamura, T. Yanagisawa, K. Takahisa, M. Nishitani, and T. Wada, "Stability of $\mathrm{Cu}(\mathrm{In}, \mathrm{Ga}) \mathrm{Se}_{2}$ Solar Cells and Evaluation by C-V Characteristics," Sol. Energy Mater. \& Sol. Cells, 50, 1998, pp. 87-95.

[24] S. S. Hegedus, and W. N. Shafarman, "Thin-Film Solar Cells: Device Measurements and Analysis," Prog. Photovolt: Res. Appl., 12, 2004, pp. 155-176.

[25] E. H. Nicollian and A. Goetzberger, "MOS Conductance Technique for Measuring Surface State Parameters," Appl. Phys. Lett., 7, 1965, pp. 216-219.

[26] R. Herberholz, M. Igalson, and H. W. Schock, "Distinction between Bulk and Interface States in CulnSe $/$ /CdS/ZnO by Space Charge Spectroscopy," J. Appl. Phys., 83, 1998, pp. 318-325. 


\section{REPORT DOCUMENTATION PAGE}

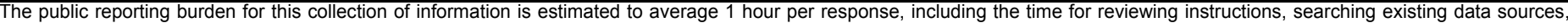

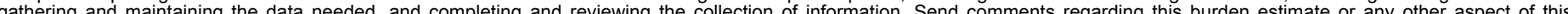
(0704-0188). Respondents

should be aware that notwithstanding any other provision of law, no person shall be subject to any penalty

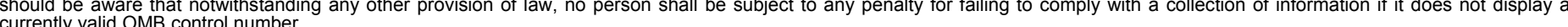

PLEASE DO NOT RETURN YOUR FORM TO THE ABOVE ORGANIZATION.

\begin{tabular}{l|l|l|l} 
1. REPORT DATE $(D D-M M-Y Y Y Y)$ & 2. REPORT TYPE & 3. DATES COVERED (FrOm - TO)
\end{tabular} January 2010

Conference Paper

4. TITLE AND SUBTITLE

Study on the Humidity Susceptibility of Thin-Film CIGS Absorber 5a. CONTRACT NUMBER

DE-AC36-08-GO28308

5b. GRANT NUMBER

5c. PROGRAM ELEMENT NUMBER

5d. PROJECT NUMBER

NREL/CP-520-45895

5e. TASK NUMBER

PVA92340

5f. WORK UNIT NUMBER
7. PERFORMING ORGANIZATION NAME(S) AND ADDRESS(ES)

National Renewable Energy Laboratory

1617 Cole Blvd.

Golden, CO 80401-3393
8. PERFORMING ORGANIZATION REPORT NUMBER

NREL/CP-520-45895

9. SPONSORING/MONITORING AGENCY NAME(S) AND ADDRESS(ES)

10. SPONSOR/MONITOR'S ACRONYM(S) NREL

11. SPONSORING/MONITORING AGENCY REPORT NUMBER

12. DISTRIBUTION AVAILABILITY STATEMENT

National Technical Information Service

U.S. Department of Commerce

5285 Port Royal Road

Springfield, VA 22161

13. SUPPLEMENTARY NOTES

14. ABSTRACT (Maximum 200 Words)

The report summarizes the research on the susceptibility of a thermally co-evaporated CulnGaSe2 (CIGS) thin-film absorber to humidity and its consequence on composition, morphology, electrical and electronic properties, and device efficiency.

15. SUBJECT TERMS

CIGS, thin-film absorber, humidity, reliability, packaging, photovoltaics

\begin{tabular}{|c|c|c|}
\hline $\begin{array}{l}\text { a. REPORT } \\
\text { Unclassified }\end{array}$ & $\begin{array}{l}\text { b. ABSTRACT } \\
\text { Unclassified }\end{array}$ & $\begin{array}{l}\text { c. THIS PAGE } \\
\text { Unclassified }\end{array}$ \\
\hline
\end{tabular}

\begin{tabular}{l|l|} 
17. & LIMITATION \\
OF ABSTRACT & $\begin{array}{l}\text { 18. } \\
\text { NUMBER } \\
\text { OF PAGES } \\
\text { UL }\end{array}$ \\
\end{tabular}

19a. NAME OF RESPONSIBLE PERSON

19b. TELEPHONE NUMBER (Include area code) 